DEMOGRAPHIC RESEARCH

VOLUME 40, ARTICLE 48, PAGES 1413-1440 PUBLISHED 30 MAY 2019

https:/www.demographic-research.org/Volumes/Vol40/48/

DOI: 10.4054/DemRes.2019.40.48

Research Article

The gendered division of labor and its perceived fairness: Implications for childbearing in Germany

Katja Köppen

Heike Trappe

(C) 2019 Katja Köppen \& Heike Trappe.

This open-access work is published under the terms of the Creative Commons Attribution 3.0 Germany (CC BY 3.0 DE), which permits use, reproduction, and distribution in any medium, provided the original author(s) and source are given credit.

See https://creativecommons.org/licenses/by/3.0/de/legalcode. 


\section{Contents}

1 Introduction 1414

$2 \quad$ Background 1415

$2.1 \quad$ Equity theory and family-related transitions 1415

$2.2 \quad$ Why Germany? 1416

2.3 Previous research on gender equality, gender equity, and 1417

$2.4 \quad$ Measurement issues 1418

3 Data and methods $\quad 1419$

$\begin{array}{ll}3.1 & \text { Data and analytic sample } \\ 3.2 & 1419\end{array}$

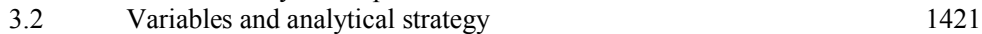

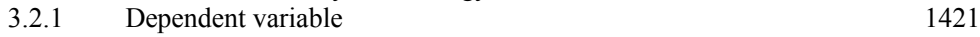

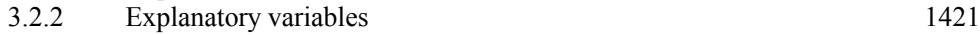

$\begin{array}{lll}3.2 .3 & \text { Other variables } & 1422\end{array}$

4 Results 1423

4.1 Descriptive findings 1423

4.2 Multivariate results: Determinants of the first birth and the second 1425

$\begin{array}{ll}\text { 4.2.1 Transition to first birth } & 1425\end{array}$

$\begin{array}{lll}\text { 4.2.2 Transition to second birth } & 1427\end{array}$

$\begin{array}{llr}5 & \text { Conclusion } & 1429\end{array}$

6 Acknowledgments 1432

$\begin{array}{ll}\text { References } & 1433\end{array}$

$\begin{array}{ll}\text { Appendix } & 1439\end{array}$ 


\title{
The gendered division of labor and its perceived fairness: Implications for childbearing in Germany
}

\author{
Katja Köppen ${ }^{1}$ \\ Heike Trappe ${ }^{2}$
}

\begin{abstract}
BACKGROUND

Recently it has been claimed that gender equality and gender equity in the family tend to increase fertility. The strength of this association, however, depends on prevailing gender relations and the level of social support of employment and family within a society.
\end{abstract}

\section{OBJECTIVE}

We wish to improve our understanding of the relationship between gender equality, gender equity, and fertility by investigating the impact of the actual division of paid and unpaid labor on first- and second-birth fertility in Germany while including in our analyses a repeatedly measured indicator of gender equity that captures the subjective perception of fairness of this division.

\section{METHODS}

Using nine waves of the German Family Panel (pairfam), we apply discrete-time logistic regression models to cohorts of young women and men in coresidential unions to determine whether a birth occurs in a given year while using measures of gender equality and gender equity as lagged time-varying covariates.

\section{RESULTS}

We find that an arrangement in which the woman is in charge of routine housework and the division of paid and unpaid work is perceived as fair is positively associated with family formation. The perception of a fair division of work is no prerequisite for continued childbearing. Yet women's responsibility for domestic work facilitates family extension.

\section{CONTRIBUTION}

This paper extends the literature on the relationship between gender equality, gender

\footnotetext{
${ }^{1}$ Universität Rostock, Germany. Email: katja.koeppen@uni-rostock.de.
}

${ }^{2}$ Universität Rostock, Germany. Email: heike.trappe@uni-rostock.de. 
equity, and family outcomes by using prospective panel data to capture attitudinal and behavioral changes over the life course more fully than has previously been done.

\section{Introduction}

A number of recent studies have asserted that there are close links between gender equality in the family and childbearing. Authors of these studies have observed that societies in which women's increasing labor force participation has been accompanied by the implementation of social policies that support both work-family reconciliation and the increasing involvement of men in domestic activities tend to have higher fertility levels than less gender-egalitarian societies (McDonald 2013). More precisely, these authors have argued that this relationship should be framed in terms of not just gender equality but also gender equity:

Gender equity is about perceptions of fairness and opportunity rather than strict equality of outcome. In relation to fertility, the equity concept allows for couples to determine the relative caring roles of the father and the mother, so long as both perceive the outcomes to be fair. What each couple considers as being fair will vary from couple to couple and from context to context (McDonald 2013: 983).

While gender equality generally refers to effective equality between women and men in terms of opportunities and - in some cases - outcomes, gender equity refers to the fairness of treatment of women and men according to their respective needs (Mencarini 2014). Scholars have further argued that perceptions of unfairness arise because individual-oriented institutions (e.g., educational and employment systems) open up new opportunities for women that are not yet supported by family-oriented institutions (McDonald 2013). If institutions designed to support the reconciliation of work and family exist, then they may be expected to reduce a potential mismatch between gender equity and gender equality (Aassve, Mencarini, and Sironi 2015). Another line of reasoning has posited that as long as the two stages of the gender revolution - first, the inclusion of women in the public sphere; second, men's increasing involvement in the domestic sphere - do not converge, women will face pressure to limit their fertility (Goldscheider, Bernhardt, and Lappegård 2015). Yet another perspective has emphasized the importance of the diffusion of genderegalitarian norms. According to this theoretical framework, perceptions of unfairness increase under conditions of unstable equilibria; that is, when there is normative 
confusion regarding appropriate gender roles and identities in family life. These scholars have therefore argued that fertility and partnership stability will decline "as the traditional equilibrium erodes and no new normative regime has taken its place" (Esping-Andersen and Billari 2015: 13).

In light of these macro-level explanations for the linkage between gender equality, gender equity, and family outcomes, we ask the following question: How are family formation and the transition to a second birth related to gender equality and the perception of fairness in Germany? This question points to the importance of withincouple negotiations concerning the division of labor and perceptions of fairness in family-related decision-making (Mills 2010). It is based on the assumption that in the contemporary context, fertility decisions are largely negotiated within a couple (Stein, Willen, and Pavetic 2014).

In this paper, we first present our theoretical idea and explain why Germany is an interesting case to study. We then summarize previous research on this topic. In the section that follows, we present our data and our analytic strategy. Subsequently, we describe our results in relation to our theoretical expectations. We close with a discussion of our findings and some directions for future research.

\section{Background}

\subsection{Equity theory and family-related transitions}

At the individual level, a person's perception of equity clearly depends on his or her level of comparison or implicit reference standard. The importance of social comparisons has been described in concepts of distributive justice. Within couples, it is assumed that both partners seek to achieve a division of labor that closely corresponds to their sense of distributive justice, because this perception is relevant for their social identity and feelings of entitlement (Perales, Baxter, and Tai 2015). Studies for Switzerland (Meuwly et al. 2011) and the United States (Stevens, Kiger, and Mannon 2005) have shown that an individual's subjective perception of the division of labor has a greater effect on his or her relationship satisfaction than the actual division of work. Thus, equity theory suggests that relationships are more harmonious when the exchange is perceived as fair. If one or both partners in a couple have unfulfilled expectations or the belief that they are not sufficiently benefiting from the relationship, they are likely to feel disappointed and dissatisfied with the partnership (Joyner 2009; Sechrist et al. 2014). Equity theory also claims that compensatory contributions are central to equity dynamics in intimate relationships. Thus, an overall sense of fairness can be maintained if a partner's smaller contributions to one domain (e.g., housework) are counter- 
balanced by larger contributions to another domain (e.g., paid work) (DeMaris and Mahoney 2017). We therefore hypothesize that, net of the actual division of labor in paid and domestic work, the stronger the perception is within a couple that the overall division of labor is fair, the more likely the partners are to transition to a first birth (Hypothesis 1).

The actual division of labor in paid and unpaid work within a couple, as well as the individual partners' perceptions of fairness, can change over the course of the relationship. In fact, there is plenty of evidence that for many couples, the transition to parenthood is an important turning point in the division of labor and, to a lesser extent, in perceptions of fairness (Perales, Baxter, and Tai 2015). Mothers tend to do the majority of domestic work, while fathers, on average, tend to work longer hours in paid employment than their female partners. The corresponding division of labor is still evaluated as fair by the majority of respondents. Based on longitudinal data for Australia, Perales, Baxter, and Tai (2015) show that the likelihood that a woman who is transitioning to parenthood will perceive the division of housework as fair increases immediately following the birth but decreases in the long run. They conclude that the transition to parenthood is often associated not only with a redistribution of housework, child care, and paid employment within the couple, as has previously been shown (Barnes 2015), but also with changes in women's and men's identities as parents and their cognitive evaluations of fairness and feelings of entitlement, as indicated by distributive justice theory (Baxter et al. 2015; Perales, Baxter, and Tai 2015).

A life course perspective suggests that experiences after the birth of the first child largely shape women's and men's expectations regarding their division of labor after an extension of their family. Whether individuals believe that the division of labor in their partnership is equitable should become increasingly important after the transition to parenthood (Luppi 2016; Lutz, Buhr, and Boehnke 2013; Torr and Short 2004). Particularly for new parents, the perception that the division of labor and child care between the partners is fair is associated with increased relationship satisfaction (Chong and Mickelson 2016). Based on prior experience, we expect to find that the transition to a second child will occur more quickly if the partners in a couple believe that their division of housework, child care, and employment is fair than if there is a wide gap between expectations and reality (Hypothesis 2).

\subsection{Why Germany?}

We argue that Germany represents an interesting case for studying the relationships between gender equality, gender equity, and childbearing because it is assumed that these relationships depend on prevailing gender relations and the level of social support 
for the reconciliation of work and family. Until the end of the 1980s, social policies in West Germany tended to promote a rather traditional gender division of labor (e.g., a limited child care supply, especially for young children). However, since reunification, a series of family policy changes has been implemented, including the enactment of a parental leave reform (2007) that created a 'partner bonus' (at least two months of leave that are exclusively reserved to the other partner) and a major expansion of public child care (since 2005). The government has also introduced new 'employability' policies (since the early 2000s) and changes in alimony regulations after divorce (2008) that provide incentives for women to take up gainful employment and that clearly represent a departure from a male breadwinner model. On the other hand, Germany's cultural norms and other social policies, many of which are still in place today (e.g., a tax system that directly penalizes wives who work full-time, the availability of health and unemployment insurance for dependent household members, and the prevalence of short part-time employment without social security benefits), continue to support a system that undermines the labor market attachment of women, and of mothers in particular (Trappe, Pollmann-Schult, and Schmitt 2015). Relative to other OECD countries, Germany has an above-average gender pay gap and a particularly high share of women - and especially mothers - who are working part-time (OECD 2017). Thus, Germany can be seen as a traditional society in which gender relations could move in a less or a more traditional direction. (For a detailed overview, see Trappe 2017.)

Recent comparative research on attitudes regarding the gendered division of paid and unpaid work has shown that western Germans overwhelmingly consider the modernized male breadwinner model (one-and-a-half-earner model) to be the ideal family model; whereas because of the legacy of state socialism, women and men in eastern Germany equally prefer the one-and-a-half-earner model and the full-time dualearner model (Edlund and Öun 2016). It is therefore not entirely clear what reference group the majority of young couples have in mind when assessing whether the gender division of labor in their family is fair. Our hypothesis is that because of institutional and normative inertia, a modernized male breadwinner model, in which the woman works part-time and is in charge of the majority of the housework and child care, is perceived as fair and is more likely to be associated with having children than an arrangement in which the partners share the paid and unpaid work more or less equally (Hypothesis 3).

\subsection{Previous research on gender equality, gender equity, and childbearing}

Previous studies on the relationship between gender equality, gender equity, and family outcomes have mainly focused on fertility or on fertility intentions and to a lesser extent 
on relationship satisfaction and partnership stability. The overall emphasis in the existing research on fertility stems from the insight that gender equity is the essential element of fertility decisions that is still missing in many low-fertility contexts, such as Germany (Mills et al. 2008). Studies that have examined the relationship between gender equity, gender equality, and fertility in European countries, Australia, Japan, and the United States have yielded mixed results. While the majority of these studies have found that couples with a more gender-equal division of labor have higher fertility (Brodmann, Esping-Andersen, and Güell 2007 for Denmark; Cooke 2004 for Germany; Cooke 2009 for Italy; Dommermuth, Hohmann-Marriott, and Lappegård 2017 for Norway; Goldscheider, Bernhardt, and Brandén 2013 for Sweden; Jansen and Liefbroer 2006 for the Netherlands; Miettinen, Lainala, and Rotkirch 2015 for Finland; Mills et al. 2008 for Italy; Nagase and Brinton 2017 for Japan; Torr and Short 2004 for the United States), other studies have not confirmed this association (Cooke 2009 for Spain; Craig and Siminski 2010 and Luppi 2016 for Australia; Torr and Short 2004 for the United States). It is likely that the discrepancies in these findings are attributable not only to contextual differences but also to measurement issues.

\subsection{Measurement issues}

Some scholars have pointed out that measuring gender equality and equity can be complex, especially in relation to fertility, and that the results can vary by parity and gender as well as by societal context (Aassve et al. 2015 for five countries; Neyer, Lappegård, and Vignoli 2013 for 11 countries). Because of the large number of measurement issues that have arisen in this field of study, the extent of these differences has been difficult to assess.

Measuring gender equity is very challenging because the concept relies on an understanding of gender equality that stresses fairness and social justice (Mencarini 2018; Neyer, Lappegård, and Vignoli 2013). Satisfaction with a given division of labor is sometimes used to measure gender equity (Dommermuth, Hohmann-Marriott, and Lappegård 2017), but this indicator is only an approximation of the perception of equity, as it is based on the assumption that people would not be satisfied with a division of labor that they perceived as unjust. Recent research has attempted to capture equity empirically by distinguishing between previous expectations and the actual division of housework (Goldscheider, Bernhardt, and Brandén 2013), between attitudes regarding gender equality and the actual division of household labor (Aassve et al. 2015), or between attitudes regarding gender equality and the division of paid and unpaid work (Oláh and Gähler 2014). Thus, the degree of consistency or inconsistency between prior attitudes and actual behavior has been used to capture equity. In most of 
these analyses, attitudes regarding gender equality were measured at one point in time, and actual behavior was measured three or four years later. Consequently, this approach neglects the possibility that individuals' attitudes, as well as their division of paid and unpaid work, might change over time. This might be an unrealistic assumption, particularly as people experience life-changing events, such as the transition to parenthood (Baxter et al. 2015).

In our view, the perception of fairness is a direct and theoretically meaningful measure for capturing equity, especially if measured repeatedly and contrasted with indicators of the actual division of employment, housework, and child care. Only a few datasets contain the information needed to assess the relative impact of the actual division of labor and its perceived fairness on the transition to childbearing. As Huinink and Feldhaus (2009: 319) emphasize, "It is not enough to measure characteristics of actors or family units at one point in time and predict 'outcomes' for actors or family units at a later time point without an examination of the whole processes evolving over a period of time." In this study, we aim to overcome some of the serious measurement issues mentioned above by accounting for the effects of the dynamics of the division of paid and unpaid work, and perceptions of the fairness of this division, on the transition to a first or a second birth over the life course. In that sense, our data comes close to what Mencarini (2018: 5) describes as ideal data to delineate the effects of gender equality and gender equity on individuals' fertility decisions.

\section{Data and methods}

\subsection{Data and analytic sample}

The analyses are based on data from the German Family Panel (Panel Analysis of Intimate Relationships and Family Dynamics, or pairfam), a multidisciplinary, longitudinal study of partnership and family dynamics in Germany (Brüderl et al. 2018a; Huinink et al. 2011). Survey data is collected annually from a nationwide random sample of more than 12,000 individuals of the birth cohorts 1971-1973, 19811983, and 1991-1993. To allow for more in-depth comparisons of family dynamics in eastern and western Germany, a subsample (DemoDiff) was drawn in 2009/2010; it oversampled eastern Germans of the cohorts 1971-1973 and 1981-1983 (Kreyenfeld et al. 2012). For this analysis, we have pooled data from wave $1(2008 / 2009)$ to wave 9 (2016/2017). As respondents can enter our sample several times, depending on how often they participated in the survey, they can contribute up to nine years of data points.

Our sample includes women and men living in a coresidential heterosexual union. While the fertility histories are collected retrospectively and are then complemented at 
each panel wave, the crucial information on levels of gender equality and gender equity among the couples has to be taken from the prospective panel waves. Childless cohabiting or married couples at any wave are studied for the transition to a first birth. Coresiding couples with one common child born before or after the start of the panel are considered at risk for the transition to a second birth at any of the waves. According to the sample selection criteria, the couples can enter the two analytic samples of childless couples and one-child parents at any wave, and they can leave the samples upon the birth of a first or second child, due to panel attrition ${ }^{3}$ or if they split up at any time during the panel. The data structure thus corresponds to an unbalanced panel.

We excluded respondents of the 1970s birth cohorts because they had an average age of 36 when the panel started and had thus largely completed their transitions to parenthood and to family extension. ${ }^{4}$ Our sample therefore includes respondents of the birth cohorts 1981-1983 and, to a lesser extent because of their young ages, 19911993.

Within each couple, only one partner was interviewed. Our final sample includes 1,927 childless couples and 975 one-child parents (see Table 1). The overrepresentation of women indicates that the women were, on average, younger than the men at childbirth. Over the nine years of the panel observation, $29 \%$ of the childless couples in our sample had a first child, while $50 \%$ of the one-child couples had a second child. The high share of parents who had a second child reflects the two-child norm in Germany and is in line with official statistics: Around 50\% of the women born in the first half of the 1980s who had one child had transitioned to a second birth by 2016 (Federal Statistical Office of Germany 2017).

\section{Table 1: $\quad$ Sample size and number of events}

\begin{tabular}{lcc}
\hline & Childless couples & One-child couples \\
\hline Men (in \%) & 45 & 40 \\
Women (in \%) & 55 & 60 \\
Person-years (subjects) & $6,683(1,927)$ & $3,392(975)$ \\
Events & 568 first births & 492 second births \\
\hline
\end{tabular}

Source: German Family Panel 2008/2009-2016/2017 (waves 1-9), cohorts 1981-1983, 1991-1993.

${ }^{3}$ Of the original sample of the two younger cohorts, more than half of the respondents were lost over the course of six waves, which is within the normal range for panel studies in Germany with this duration, particularly for this age group (Müller and Castiglioni 2015).

${ }^{4}$ Before wave 1, almost $75 \%$ of the 1970 s birth cohorts had already had one child, and $47 \%$ had had two children. The share of respondents with at least one child before the start of the panel is much smaller within the two younger cohorts: One-quarter of the 1980s cohorts had given birth to a first child before wave $1(15 \%$ of men, $38 \%$ of women), while $10 \%$ had given birth to a second child (5\% of men, $15 \%$ of women). Only three respondents born between 1991 and 1993 were already parents before the panel started. Therefore, problems resulting from the late entry into the risk set are much reduced. 


\subsection{Variables and analytical strategy}

\subsubsection{Dependent variable}

We have information on whether a birth occurred between wave $\mathrm{x}-1$ and wave $\mathrm{x}$ or whether the respondent or the respondent's partner was pregnant at wave $\mathrm{x}$. For the multivariate analysis, two dependent variables are studied: (1) being pregnant with or having a first child and (2) being pregnant with or having a second child with the same partner. Censoring occurs in case of separation or if the respondent continues the relationship with the current partner without experiencing any of the transitions of interest.

\subsubsection{Explanatory variables}

Our analysis includes four main explanatory variables that are time-varying: a couple's employment arrangement, a couple's division of child care, a couple's division of housework, and the respondent's overall perception of fairness. The first variable is broken down into the five most common employment constellations within which parttime and full-time employment are distinguished based on respondents' selfassessments. Housework encompasses routine chores, such as doing the laundry, cooking, and cleaning. ${ }^{5}$ The division of housework and child care has been recoded into the categories of completely or mainly done by the woman or the man, as compared to being shared roughly equally. ${ }^{6}$ The perception of fairness regarding the division of domestic and paid work was measured using the following question: "Looking at both housework and paid work: How fair is the division of labor between you and your partner?"7 The possible responses were: I do "much more than," "a bit more than," "about," "a bit less than," or "much less than" my fair share. A new variable that collapses the categories of "much" and "a bit" and that takes into account the respondent's gender has been constructed. Thus, this variable indicates whether the division was seen as unfair to the woman, unfair to the man, or fair to both. The information used for the generation of the main explanatory variables was collected yearly, with the exception of information on the perception of equity, which was collected every other year. If this information was lacking, we took the value from the

\footnotetext{
${ }^{5}$ Because our focus is on routine chores that have to be done regularly, we excluded occasional tasks, such as making repairs and handling administrative matters.

${ }^{6}$ The aggregation of categories was necessary to ensure a sufficient number of cases in analyses separated by gender.

${ }_{7}^{7}$ Interestingly, and in contrast to much of the previous research on the impact of the equity perception on family outcomes (Luppi 2016), this variable includes paid work but does not consider child care.
} 
Köppen \& Trappe: The gendered division of labor and its perceived fairness

previous wave. Including these four main explanatory variables as time-varying indicators that were measured over up to nine years enables us to investigate the processual nature of gender inequality and gender equity, and their impact on childbearing over the life course. ${ }^{8}$ To avoid problems of reverse causality, any timevarying information in the explanatory variables has been lagged by one year prior to the transition of interest.

\subsubsection{Other variables}

We also controlled for a host of other time-varying variables that were identified in previous research as important for fertility: duration of cohabitation, age of the respondent, age of the first child, whether the respondent is in a marital or a nonmarital union, the self-assessed importance of having children and having a career, ${ }^{9}$ and the highest vocational degree of the respondent and the partner. The time-constant variables include gender and the respondent's country or region of birth.

We first present our descriptive findings on the composition of the couples. The descriptive information is displayed as weighted estimates. Here, we use a combination of a design and a poststratification weight that accounts for the oversampling of eastern Germany in the sample (Brüderl et al. 2018b). Finally, the determinants of family formation and the transition to a second birth are examined in a multivariate framework. Based on previous research (Aassve et al. 2015; Goldscheider, Bernhardt, and Brandén 2013; Neyer, Lappegård, and Vignoli 2013), we present our models for all respondents as well as separately for women and men and by parity. To run separate analyses by gender and by parity takes into account a potentially varying impact of gender equality and gender equity as well as the differential timing of births over the life course. Since the perception of fairness was surveyed every other year, a sensitivity analysis has been conducted by removing the data from the years when this information had not been collected. However, the main results remained stable. Another robustness check has been done because of the relatively young age of our respondents. Members of the 1980s cohorts were on average between 34 and 35 years old when the observation period ended, while members of the 1990s cohorts were ten years younger, thus contributing far fewer events to the analysis. Restricting the analysis to women and men born in the years 1981-1983 basically yielded the same results as the total sample.

\footnotetext{
${ }^{8}$ Multicollinearity between the four main explanatory variables is only moderate.

${ }^{9}$ At each wave, respondents were asked to distribute 15 points among five life goals according to their current importance. Out of those five items, the following two were selected: "pursuing my education or career interests" and "having a(nother) child." The scales have been recoded to a value range between 0 and 10.
} 
We use discrete-time logistic regression models to estimate the transition to a first pregnancy/birth for the childless couples and to a second pregnancy/birth for the onechild parents. This method easily accounts for censoring, and it allows us to measure the risk of an event at each time point (i.e., yearly). Moreover, this approach enables us to measure how both time-varying and time-constant characteristics affect the odds of having a (further) child (Allison 1984). To account for multiple observations of identical respondents in the sample, robust standard errors were calculated. As the results turned out to be robust to different specifications, we decided against a stepwise modeling procedure.

\section{Results}

\subsection{Descriptive findings}

In this section, we highlight the main explanatory variables. Table 2 provides a descriptive overview of all the variables used in the analyses. The couples' employment arrangements differed in the expected ways, depending on whether they had children. The share of couples in which both partners were working full-time was much higher among the childless couples than among the parents (38\% versus $10 \%)$. Similarly, the share of the couples in which the male partner was working full-time and the female partner was working part-time or was on parental leave was especially large among the parents. By contrast, a larger share of the childless couples than the parents reported that at least one partner was (still) in education. Among childless couples, more than half of the respondents reported that they were sharing the housework about equally, while almost $40 \%$, particularly among female respondents, conceded that the woman was doing most or all of the housework. In comparison, less than one-third of the parents said they were sharing the housework equally, with more than $70 \%$ (even more among female respondents) reporting that the woman was doing most or all of the routine housework. It appears that the fathers were only slightly more involved in child care than in housework, with $28 \%$ of the parents saying that the division of child care was about equal but with $70 \%$ conceding that the woman was doing most of the child care. 
Köppen \& Trappe: The gendered division of labor and its perceived fairness

Table 2: Descriptive statistics (column percentages)

\begin{tabular}{|c|c|c|c|c|c|c|}
\hline & \multicolumn{3}{|c|}{ Childless couples } & \multicolumn{3}{|c|}{ One-child couples } \\
\hline & All & Men & Women & All & Men & Women \\
\hline \multicolumn{7}{|l|}{ Couples' employment arrangements } \\
\hline Both work full-time & 38 & 37 & 39 & 10 & 9 & 11 \\
\hline $\begin{array}{l}\text { Man works full-time/woman works part-time } \\
\text { or is marginally employed }\end{array}$ & 5 & 5 & 5 & 18 & 18 & 19 \\
\hline $\begin{array}{l}\text { Man works full-time/woman is on parental } \\
\text { leave }\end{array}$ & - & - & - & 43 & 43 & 43 \\
\hline Man and/or woman in education & 26 & 30 & 24 & 12 & 14 & 11 \\
\hline Other combinations & 25 & 24 & 26 & 16 & 16 & 17 \\
\hline Missing & 6 & 5 & 6 & - & - & - \\
\hline \multicolumn{7}{|l|}{ Division of housework } \\
\hline Completely/mainly done by woman & 37 & 34 & 39 & 71 & 67 & 74 \\
\hline $50 / 50$ & 53 & 54 & 53 & 26 & 30 & 23 \\
\hline Completely/mainly done by man & 4 & 5 & 3 & 3 & 3 & 3 \\
\hline Missing & 6 & 7 & 5 & - & - & - \\
\hline \multicolumn{7}{|l|}{ Division of child care } \\
\hline Completely/mainly done by woman & - & - & - & 70 & 68 & 72 \\
\hline $50 / 50$ & - & - & - & 28 & 30 & 26 \\
\hline Completely/mainly done by man & - & - & - & 2 & 2 & 2 \\
\hline \multicolumn{7}{|l|}{ Perception of fairness } \\
\hline Unfair to the woman & 24 & 16 & 29 & 27 & 19 & 33 \\
\hline Fair to both & 62 & 68 & 58 & 69 & 75 & 65 \\
\hline Unfair to the man & 6 & 7 & 5 & 4 & 6 & 2 \\
\hline Missing & 8 & 9 & 8 & - & - & - \\
\hline Years since age $14 /$ since first birth (mean) & 11.7 & 12.3 & 11.2 & 1.3 & 1.2 & 1.4 \\
\hline For birth cohort 1981-1983 & 14.6 & 14.8 & 14.4 & 1.4 & 1.2 & 1.5 \\
\hline For birth cohort 1991-1993 & 6.7 & 6.9 & 6.6 & 0.6 & 0.6 & 0.5 \\
\hline Duration of cohabitation in years (mean) & 2.4 & 2.3 & 2.5 & 4.9 & 4.6 & 5.1 \\
\hline Respondent is a woman (vs. man) & 58 & - & - & 58 & - & - \\
\hline \multicolumn{7}{|l|}{ Place of birth } \\
\hline Western Germany & 82 & 80 & 84 & 65 & 67 & 63 \\
\hline Eastern Germany & 9 & 11 & 7 & 18 & 17 & 19 \\
\hline Abroad & 9 & 9 & 9 & 17 & 16 & 18 \\
\hline Couple is cohabiting (vs. married) & 79 & 80 & 79 & 30 & 32 & 28 \\
\hline $\begin{array}{l}\text { Importance of children (mean, } 0-10 \text { with } \\
10 \text { as most important) }\end{array}$ & 1.0 & 1.0 & 1.1 & 1.7 & 1.6 & 1.8 \\
\hline $\begin{array}{l}\text { Importance of a career (mean, } 0-10 \text { with } \\
10 \text { as most important) }\end{array}$ & 2.5 & 2.6 & 2.4 & 1.9 & 2.1 & 1.7 \\
\hline \multicolumn{7}{|l|}{ Couples' education } \\
\hline Both no degree & 18 & 20 & 15 & 8 & 9 & 7 \\
\hline Both vocational degree & 26 & 28 & 26 & 41 & 44 & 40 \\
\hline Both university degree & 14 & 11 & 16 & 15 & 13 & 17 \\
\hline Her education lower than his & 25 & 23 & 26 & 22 & 24 & 20 \\
\hline His education lower than hers & 17 & 18 & 17 & 14 & 10 & 17 \\
\hline $\mathrm{N}$ (person-years) & 6,683 & 3,029 & 3,654 & 3,392 & 1,315 & 2,077 \\
\hline
\end{tabular}

Source: German Family Panel 2008/2009-2016/2017 (waves 1-9), cohorts 1981-1983, 1991-1993, weighted results. 
Surprisingly, despite the huge differences between the childless couples and the parents in the actual division of work, the overall perception of the fairness of the division of paid and domestic work differed only slightly between the two groups. In line with previous research on this paradoxical situation (Perales, Baxter, and Tai 2015; Ruppanner, Bernhardt, and Brandén 2017; Trappe and Köppen 2014), we find that about two-thirds of all the couples in the sample said they consider their division of labor fair, with an even higher share among the one-child parents. Less than one-third said they believe their division of labor is unfair to the woman. However, there are distinct gender differences, with female respondents reporting considerably more often than male respondents that the division of paid and unpaid work is unfair to the woman. Overall, these findings confirm our assumption that in Germany, women do most of the housework and child care, and that most couples accept this arrangement.

\subsection{Multivariate results: Determinants of the first birth and the second birth}

The results of the discrete-time logistic regression analyses are presented with an emphasis on the main explanatory variables that focus on the division of work and perceptions of the fairness of this arrangement (Table 3). Regression results in Table 3 are provided as relative odds, with indicators of various levels of significance. Untransformed coefficients and the full range of standard errors can be found in the Appendix (Tables A-1 and A-2). First we comment on the results for childless couples and point out potential differences between female and male respondents. We then discuss the findings for one-child parents.

\subsubsection{Transition to first birth}

A couple's employment arrangement had a moderate impact on the odds of transitioning to a first birth. As long as one of the partners was (still) in education, the transition rate of having a first child was reduced. The effect reached statistical significance among male respondents only, possibly reflecting that female respondents were partnered with somewhat older men on average. This pattern mirrors the general perception that education and family formation are difficult to reconcile and that having entered the labor force is a prerequisite for starting a family. Contrary to Hypothesis 3, we find no significant differences in the odds of family formation between the couples in which both partners were working full-time and those in which the woman was working part-time. However, this might be more relevant for the extension of a family than for family formation. Interestingly, the division of household labor had a slightly 
positive impact on the rate of transition to a first birth: Couples in which the woman was doing the bulk of the routine housework were significantly more likely to have started a family than those in which the housework was shared about equally. Presumably due to the relatively small sample size, this effect is only marginally significant in Model 1 but points in the same direction among female and male respondents. In line with our expectation (Hypothesis 1), we find that net of the actual division of paid and unpaid work, the perception of the fairness of this arrangement mattered. The odds of having a first child were about $20 \%$ lower among respondents who indicated that they perceive their division of labor as unfair to the woman than among those who said they perceive it as fair to both.

To better understand the somewhat contradictory results for the measures of couples' employment arrangements, division of housework, and perception of fairness, we specified models containing two-way interactions between each two of these measures. As the inclusion of the interaction terms did not add to the explanatory power of the models, this indicates that the effects of the variables are additive rather than multiplicative. However, a closer descriptive inspection of the interrelations between paid work, housework, and fairness perception suggests that working hours mattered. If both partners worked full-time, the woman did the majority of housework, and this was considered fair to both, men worked on average almost six hours longer than women (45.5 hours versus 39.9 hours). If such a constellation was perceived as unfair to the woman, working hours differed to a lesser extent (43.6 hours for men versus 41 hours for women). This hints at the idea of distributive justice: Among full-time working couples with differential working hours, gainful employment might be traded against housework to maintain an overall sense of fairness.

Other variables that turned out to be important for the transition to a first birth among childless couples were partly demographic. Being older and being married increased the odds of a first birth. It thus appears that in a social context in which marriage is clearly supported by law and the social security system, as is the case in Germany, marriage is still the most preferred relationship form among couples who are starting a family. The couples in which the female partner had a lower educational degree than the male partner had lower transition rates to parenthood than the couples in which both partners had a vocational degree. If both partners had a university degree, they transitioned faster to parenthood, probably indicating 'a catching up' after having left the educational system. It is noteworthy that respondents who said in a prior wave that they place a high degree of importance on having children were also more likely to make this transition. In other words, there was self-selection into parenthood. On the other hand, those who reported that they place a high degree of importance on having a career transitioned to a first birth considerably more slowly than others. A significant negative impact of a career orientation is found for women only. Again, it appears that 
Germany's cultural norms and long-standing legacy of social policies that favor a clear gender division of labor continue to make combining work and family life rather difficult for women in particular.

\subsubsection{Transition to second birth}

We find that the main explanatory variables for gender equality and gender equity among couples had small and unexpected effects on the transition to a second birth among the parents with one common child. Couples in which women were working reduced hours did not differ significantly from couples in which both partners were working full-time in their odds of a second birth (Hypothesis 3), but couples in which the woman was still on parental leave transitioned more slowly to a second birth than full-time working couples. This might be related to the expansion of public child care (since 2005) and the enactment of a parental leave reform (2007) in Germany, which both supported comparatively short employment interruptions and mothers' earlier return to the labor market (Geyer, Haan, and Wrohlich 2015). As for the transition to family formation, couples in which the woman was doing the lion's share of housework had higher odds of a second birth than those couples who shared it about equally. Neither the division of child care nor the fairness perception had a noticeable impact on the odds of family extension for couples with one common child. The absence of such effects is surprising and is in contrast to our expectation that the perception of the fairness of the division of gainful employment and domestic work is increasingly important for fertility transitions over the life course (Hypothesis 2). Instead, our findings suggest that couples transitioned even faster to a second birth when women did most of the routine housework and that the perceived fairness of the division between paid and unpaid work did not matter at all. Thus, whereas research in other countries, such as Denmark, has shown that couples bargain over family extension, this does not appear to be the case in Germany (Brodmann, Esping-Andersen, and Güell 2007).

Being in a longer-lasting coresidential union increased the odds of a second birth, while eastern Germans show a lower transition rate than western Germans. As for the transition to family formation, we find that marital status and the self-assessed importance of children were relevant for family extension. The parents who were still in a nonmarital union had lower odds of a second birth than those who were married. The women and men who said they see having children as an important life goal transitioned faster to a second birth. Solely women who reported that they place greater emphasis on having an occupational career had a significantly reduced transition rate to a second birth, which again points to the difficulties women in particular face in pursuing a career while raising children. Interestingly, our findings indicate that 
education had pronounced effects: Compared to the couples with vocational degrees, the couples in which both partners' education diverged or in which both partners had a university degree transitioned to a second child faster. When we look at the latter effect more closely, we see that most of these respondents had a technical college degree, which takes less time to complete than a university degree. In addition, previous research has shown a positive association between education and higher-order births in western Germany, mostly due to the closer spacing of children within this educational group but also due to selection effects and the importance of having a well-educated male breadwinner in the family (Kreyenfeld 2002; Köppen 2006).

An additional descriptive analysis that included data on only the 207 couples who had given birth to a first and a second child since the collection of the prospective panel data started reveals a considerable and even more pronounced trend toward a traditional gendered division of paid work and housework over the course of family formation and extension than the findings in Table 2 suggest. For instance, before the birth of the first child, $49 \%$ of the couples reported that they were sharing routine housework about equally, whereas before the birth of the second child, this proportion had halved. However, $68 \%$ of the respondents indicated that they considered their division of labor fair before their first child was born, and $72 \%$ said they considered this division fair after the birth. Although these findings are based on a small and selective sample, they are important because they exemplify that it is not only the actual division of work within a couple that changes in the course of family formation but also the normative frames used to assess fairness.

Table 3: Discrete-time logistic regression models of transitions to the first birth and the second birth (with robust standard errors)

\begin{tabular}{|c|c|c|c|c|c|c|}
\hline & \multicolumn{3}{|c|}{ Transition to first birth } & \multicolumn{3}{|c|}{ Transition to second birth } \\
\hline & $\begin{array}{c}\text { All } \\
\text { Model } 1\end{array}$ & $\begin{array}{c}\text { Men } \\
\text { Model } 2\end{array}$ & $\begin{array}{l}\text { Women } \\
\text { Model } 3\end{array}$ & $\begin{array}{c}\text { All } \\
\text { Model } 4\end{array}$ & $\begin{array}{c}\text { Men } \\
\text { Model } 5\end{array}$ & $\begin{array}{l}\text { Women } \\
\text { Model } 6\end{array}$ \\
\hline \multicolumn{7}{|c|}{ Couples' employment arrangements (ref.: both full-time) } \\
\hline $\begin{array}{l}\text { Man full-time/woman part-time or } \\
\text { marginally employed }\end{array}$ & 0.99 & 0.92 & 1.02 & 0.87 & 1.21 & 0.72 \\
\hline Man full-time/woman on parental leave & - & - & - & $0.48^{* * *}$ & 0.75 & 0.36 *** \\
\hline Man and/or woman in education & 0.72 ** & 0.59 ** & 0.82 & 0.84 & 0.91 & 0.84 \\
\hline Other combinations & 0.91 & 0.89 & 0.89 & $0.50 * * *$ & 0.75 & $0.39^{* * *}$ \\
\hline \multicolumn{7}{|l|}{ Division of housework (ref.: $50 / 50$ ) } \\
\hline Completely/mainly done by woman & 1.22 * & 1.20 & 1.20 & 1.28 ** & 1.22 & $1.33^{*}$ \\
\hline Completely/mainly done by man & 0.86 & 1.03 & 0.67 & 1.38 & 0.99 & 1.58 \\
\hline \multicolumn{7}{|l|}{ Division of child care (ref.: 50/50) } \\
\hline Completely/mainly done by woman & & & & 1.10 & 1.25 & 0.98 \\
\hline Completely/mainly done by man & & & & 0.92 & 0.71 & 0.98 \\
\hline \multicolumn{7}{|l|}{ Perception of fairness (ref.: fair to both) } \\
\hline Unfair to the woman & 0.82 * & 0.75 & 0.88 & 0.84 & 0.82 & 0.89 \\
\hline Unfair to the man & 1.00 & 0.92 & 1.07 & 0.93 & 1.04 & 0.73 \\
\hline
\end{tabular}


Table 3: (Continued)

\begin{tabular}{|c|c|c|c|c|c|c|}
\hline & \multicolumn{3}{|c|}{ Transition to first birth } & \multicolumn{3}{|c|}{ Transition to second birth } \\
\hline & $\begin{array}{c}\text { All } \\
\text { Model } 1\end{array}$ & $\begin{array}{c}\text { Men } \\
\text { Model } 2\end{array}$ & $\begin{array}{l}\text { Women } \\
\text { Model } 3\end{array}$ & $\begin{array}{c}\text { All } \\
\text { Model } 4\end{array}$ & $\begin{array}{c}\text { Men } \\
\text { Model } 5\end{array}$ & $\begin{array}{l}\text { Women } \\
\text { Model } 6\end{array}$ \\
\hline Years since age 14/since first birth & $1.12^{\star \star \star}$ & $1.18^{* * *}$ & $1.08^{* * *}$ & 1.04 & 1.04 & 1.04 \\
\hline Duration of cohabitation (cont.) & 1.00 & 0.97 & 1.01 & $1.05^{* * *}$ & 1.05 & 1.06 ** \\
\hline Respondent is a woman (ref.: man) & 0.93 & - & - & 0.87 & - & - \\
\hline \multicolumn{7}{|l|}{ Place of birth (ref.: western Germany) } \\
\hline Eastern Germany & 1.16 & 1.04 & 1.30 * & $0.74^{* \star *}$ & 0.85 & $0.66^{\star * \star}$ \\
\hline Abroad & 0.88 & 0.83 & 0.89 & 0.75 * & 0.70 & 0.75 \\
\hline Couple is cohabiting (ref.: married) & $0.55^{\star \star \star}$ & $0.48^{* * *}$ & $0.60^{* * *}$ & $0.50^{* \star *}$ & $0.52^{* * *}$ & $0.48^{* * *}$ \\
\hline Importance of children $(0-10)$ & $1.52^{\star \star \star *}$ & $1.55^{\star * \star}$ & $1.52^{\star \star \star}$ & $1.39 * * *$ & $1.43^{* \star *}$ & $1.36^{* \star *}$ \\
\hline Importance of a career $(0-10)$ & $0.88^{* *}$ & 0.93 & $0.85^{* *}$ & $0.89 * *$ & 1.03 & $0.80^{* * *}$ \\
\hline \multicolumn{7}{|c|}{ Couples' education (ref.: both vocational degree) } \\
\hline Both no degree & 0.83 & 0.95 & 0.78 & 1.26 & 1.38 & 1.11 \\
\hline Both university degree & 1.28 * & $1.53^{* *}$ & 1.12 & $2.42^{* \star *}$ & 1.58 * & $3.07^{* \star *}$ \\
\hline Her education lower than his & $0.67^{\star \star \star *}$ & $0.60^{* *}$ & 0.71 & $1.53^{* \star *}$ & 1.35 & $1.58^{* *}$ \\
\hline His education lower than hers & 0.83 & 1.19 & 0.64 ** & $1.49^{* \star *}$ & $1.57^{*}$ & $1.46^{* *}$ \\
\hline Constant & $0.03^{* \star *}$ & $0.01^{\star * *}$ & $0.04^{\star \star *}$ & $0.12^{* \star *}$ & $0.06^{* * *}$ & $0.15^{* * *}$ \\
\hline Wald $x^{2}$ & 375.24 & 214.56 & 201.27 & 209.64 & 49.74 & 188.34 \\
\hline Pseudo $\mathrm{R}^{2}$ & 0.13 & 0.15 & 0.13 & 0.09 & 0.07 & 0.11 \\
\hline Events/person-years & $568 / 6,683$ & $267 / 3,029$ & $301 / 3,654$ & $492 / 3,392$ & $185 / 1,315$ & $307 / 2,077$ \\
\hline
\end{tabular}

Note: Controlled for missing information on employment arrangement, division of housework, and fairness perception (omitted from the table). ${ }^{* * *} p<0.01,{ }^{* \star} p<0.05,{ }^{*} p<0.1$.

Source: German Family Panel 2008/2009-2016/2017 (waves 1-9), cohorts 1981-1983, 1991-1993.

\section{Conclusion}

Contrary to our expectations, we find that in our sample of couples in Germany, equality and equity in the family were not necessarily associated with higher levels of fertility. Among these young women and men, the entry into employment of both partners was generally deemed necessary to start a family. In addition, a rather traditional division of domestic labor, in which the woman was doing most of the work, was associated with a higher transition to family formation. Even though more than half of the childless couples reported that they were sharing routine housework rather equally, this arrangement did not foster family formation, as has been shown for Norway (Dommermuth, Hohmann-Marriott, and Lappegård 2017) and for Finland (Miettinen, Lainala, and Rotkirch 2015). The results for Germany suggest that processes of traditionalization that are conducive to family formation start prior to the birth of a first child. It may be the case that couples who intend to start a family soon anticipate their future division of work in the course of this life-changing event and adapt their perceptions of fairness accordingly (Baxter et al. 2015). These results are further backed up by our finding that having a strong career orientation and having a strong family orientation had opposite effects on the transition to parenthood, 
particularly for women. It might be argued that the self-assessed relevance of different life goals was endogenous to having children, but we tried to disentangle this relationship by ensuring that the individual orientation had been measured prior to the transition of interest. In our view, the effect mainly points to the self-selection into parenthood of women with a strong family orientation and a weaker career orientation. Our ability to offer this interpretation reflects the strength of the analytical approach of this study: By following our respondents over nine successive panel years, while repeatedly measuring their objective behavior and their subjective perceptions in the year before any of the events of interest occurred, we were able to capture changes over the life course in both dimensions and to alleviate problems of reverse causality (Huinink and Feldhaus 2009). Unlike in the Nordic countries (e.g., Ruppanner, Bernhardt, and Brandén 2017), in Germany the shift toward social policies and a public discourse supporting a more gender-equal division of labor in the workplace and at home has only recently started to occur and has been developing unevenly. Thus, the impact of behavioral and normative changes away from a family ideal in which domestic work is largely the responsibility of the woman might be limited. Women continue to report challenges in reconciling family with career that are attributable in large part to a long legacy of social policies in Germany that favored a rather traditional division of labor. Moreover, recent research suggests that in Germany the adherence to stereotypical gender roles is still quite common, since fathers report the highest level of life satisfaction when working full-time or even longer (Schröder 2018).

Although the majority of previous studies on this topic suggested that an equal division of housework and child care - and, to an even greater extent, the perception that this division is equitable - is advantageous for continued childbearing, especially in countries with a strong emphasis on egalitarian gender roles, such as the Scandinavian societies (e.g., Brodmann, Esping-Andersen, and Güell 2007; Dommermuth, HohmannMarriott, and Lappegård 2017; Goldscheider, Bernhardt, and Brandén 2013; Miettinen, Lainala, and Rotkirch 2015), we were unable to replicate these findings for young cohorts of couples in Germany. Instead, women's main responsibility for domestic work had a positive impact on the timing of a second birth with the same partner, while the division of child care and the perception of fairness had no noticeable effect. It thus appears that among these couples, the decision about whether to extend the family was not bargained on the basis of gender equality and equity but rather followed a selection into partnership, parenthood, and a prevailing two-child norm. Again, we find a positive impact of family orientation and a negative impact of career orientation on the transition to a second birth for women but not for men, which underlines the problems women in Germany still face in reconciling the demands of career and family. Overall, our findings underscore the context-dependency of explanations of the effects of equality and equity within the family on childbearing. 
However, since our deliberatively chosen focus was on continued childbearing with the same partner, and thus on the life course beyond the individual, it may well be the case that for couples who split up after family formation, issues of gender equality and fairness are more prevalent, especially when considering having another child. Due to the relatively young age of the respondents in our study, there is also the possibility that the impact of gender equity on the extension of a family has been underestimated. This might be the case if women and men who highly value a fair division of domestic and paid work tend to have a second birth later in life, and it should thus be subject to further investigation.

Additional analysis based on the data of the couples who had their first and second child during the panel observation period once again shows the well-documented traditionalization of the division of labor in the course of family formation (e.g., Grunow, Schulz, and Blossfeld 2007; Nitsche and Grunow 2016). More importantly, as the results also indicate that an increasingly gendered division of work over the course of family formation was perceived as fair by these couples, it is possible that their relationships were subject to processes of habituation and adaptation. This finding might also imply that the implicit reference standards for the assessment of fairness change after the transition to parenthood because of shifting identities and cognitive beliefs (Baxter et al. 2015). Particularly during the interruption of a woman's participation in the labor market after family formation, the idea of an equitable division of paid and unpaid work might be overlaid by a concept of equity that is less about sharing tasks equally than about investing comparable amounts of time into employment or into the household and child care (Grunow, Schulz, and Blossfeld 2007).

In our view, future research should explicitly address the questions of whether and how fairness norms change over the course of family formation and extension. Moreover, given the availability of even more nuanced life course data, the distinction between transitions to higher-order births with the same or with a new partner might be a promising research trajectory. An obvious improvement on the present study would be to use information on both partners' characteristics provided by both partners. This would be particularly important for the subjective measures of the distribution of unpaid labor and the perception of fairness. To account fully for the theoretical arguments that have been raised here and in comparable studies, researchers would need to have access to long waves of prospective panel data with reliable indicators of equality and equity that have been measured repeatedly for both partners in a couple. Currently, however, no such dataset exists (Aassve et al. 2015; Mencarini 2018). 
Köppen \& Trappe: The gendered division of labor and its perceived fairness

\section{Acknowledgments}

This paper uses data from the German Family Panel (pairfam), coordinated by Josef Brüderl, Sonja Drobnič, Karsten Hank, Bernhard Nauck, Franz Neyer, and Sabine Walper. Pairfam is funded as a long-term project by the German Research Foundation (DFG). 


\section{References}

Aassve, A., Fuochi, G., Mencarini, L., and Mendola, D. (2015). What is your couple type? Gender ideology, housework sharing, and babies. Demographic Research 32(30): 835-858. doi:10.4054/DemRes.2015.32.30.

Aassve, A., Mencarini, L., and Sironi, M. (2015). Institutional change, happiness, and fertility. European Sociological Review 31(6): 749-765. doi:10.1093/esr/jcv073.

Allison, P.D. (1984). Event history analysis: Regression for longitudinal event data. Beverly Hills: Sage. doi:10.4135/9781412984195.

Barnes, M.W. (2015). Gender differentiation in paid and unpaid work during the transition to parenthood. Sociology Compass 9(5): 348-364. doi:10.1111/soc4. 12263.

Baxter, J., Buchler, S., Perales, F., and Western, M. (2015). A life-changing event: First births and men's and women's attitudes to mothering and gender divisions of labor. Social Forces 93(3): 989-1014. doi:10.1093/sf/sou103.

Brodmann, S., Esping-Andersen, G., and Güell, M. (2007). When fertility is bargained: Second births in Denmark and Spain. European Sociological Review 23(5): 599-613. doi:10.1093/esr/jcm025.

Brüderl, J., Drobnič, S., Hank, K., Huinink, J., Nauck, B., Neyer, F.J., Walper, S., Alt, P., Borschel, E., Bozoyan, C., Finn, C., Garrett, M., Greischel, H., Hajek, K., Herzig, M., Huyer-May, B., Lenke, R., Müller, B., Peter, T., Schmiedeberg, C., Schütze, P., Schumann, N., Thönnissen, C., Wetzel, M., and Wilhelm, B. (2018a). The German Family Panel (pairfam): Version 9.1.0 [electronic resource]. Cologne: GESIS Data Archive. doi:10.4232/pairfam.5678.9.1.0.

Brüderl, J., Hajek, K., Herzig, M., Lenke, R., Müller, B., Schütze, P., and Schumann, N. (2018b). pairfam data manual: Release 9.1. München: LMU. http://www.pairfam.de/fileadmin/user_upload/redakteur/publis/Dokumentation/ Manuals/Data_Manual_pairfam_9.1.pdf.

Chong, A. and Mickelson, K.D. (2016). Perceived fairness and relationship satisfaction during the transition to parenthood: The mediating role of spousal support. Journal of Family Issues 37(1): 3-28. doi:10.1177/0192513X13516764.

Cooke, L.P. (2004). The gendered division of labor and family outcomes in Germany. Journal of Marriage and Family 66(5): 1246-1259. doi:10.1111/j.0022-2445. 2004.00090.x. 
Cooke, L.P. (2009). Gender equity and fertility in Italy and Spain. Journal of Social Policy 38(1): 123-140. doi:10.1017/S0047279408002584.

Craig, L. and Siminski, P. (2010). Men's housework, women's housework, and second births in Australia. Social Politics: International Studies in Gender, State and Society 17(2): 235-266. doi:10.1093/sp/jxq004.

DeMaris, A. and Mahoney, A. (2017). Equity dynamics in the perceived fairness of infant care. Journal of Marriage and Family 79(1): 261-276. doi:10.1111/ jomf.12331.

Dommermuth, L., Hohmann-Marriott, B., and Lappegård, T. (2017). Gender equality in the family and childbearing. Journal of Family Issues 38(13): 1803-1824. doi:10.1177/0192513X15590686.

Edlund, J. and Öun, I. (2016). Who should work and who should care? Attitudes towards the desirable division of labour between mothers and fathers in five European countries. Acta Sociologica 59(2): 151-169. doi:10.1177/000169931 6631024.

Esping-Andersen, G. and Billari, F.C. (2015). Re-theorizing family demographics. Population and Development Review 41(1): 1-31. doi:10.1111/j.1728-4457.20 15.00024.x.

Federal Statistical Office of Germany (2017). Kinderlosigkeit, Geburten und Familien: Ergebnisse des Mikrozensus 2016 [Childlessness, births and families: Results of the microcensus 2016]. Wiesbaden: Statistisches Bundesamt. https://www.destatis.de/DE/Presse/Pressekonferenzen/2017/Mikrozensus-2017/ pressebroschuere-mikrozensus.pdf?_blob=publicationFile \&v=2.

Geyer, J., Haan, P., and Wrohlich, K. (2015). The effects of family policy on maternal labor supply: Combining evidence from a structural model and a quasiexperimental approach. Labour Economics 36: 84-98. doi:10.1016/j.labeco.20 15.07.001.

Goldscheider, F., Bernhardt, E., and Brandén, M. (2013). Domestic gender equality and childbearing in Sweden. Demographic Research 29(40): 1097-1126. doi:10.40 54/DemRes.2013.29.40.

Goldscheider, F., Bernhardt, E., and Lappegård, T. (2015). The gender revolution: A framework for understanding changing family and demographic behavior. Population and Development Review 41(2): 207-239. doi:10.1111/j.1728-44 57.2015.00045.x. 
Grunow, D., Schulz, F., and Blossfeld, H.-P. (2007). Was erklärt die Traditionalisierungsprozesse häuslicher Arbeitsteilung im Eheverlauf: Soziale Normen oder ökonomische Ressourcen? [What explains the process of traditionalization in the division of household labor: Social norms or economic resources?] Zeitschrift für Soziologie 36(3): 162-181. doi:10.1515/zfsoz-20070301.

Huinink, J. and Feldhaus, M. (2009). Family research from the life course perspective. International Sociology 24(3): 299-324. doi:10.1177/0268580909102910.

Huinink, J., Brüderl, J., Nauck, B., Walper, S., Castiglioni, L., and Feldhaus, M. (2011). Panel analysis of intimate relationships and family dynamics (pairfam): Conceptual framework and design. Zeitschrift für Familienforschung 23(1): 77101.

Jansen, M. and Liefbroer, A.C. (2006). Couples' attitudes, childbirth, and the division of labor. Journal of Family Issues 27(11): 1487-1511. doi:10.1177/0192513X 06291038 .

Joyner, K. (2009). Justice and the fate of married and cohabiting couples. Social Psychology Quarterly 72(1): 61-76. doi:10.1177/019027250907200106.

Köppen, K. (2006). Second births in western Germany and France. Demographic Research 14(14): 295-330. doi:10.4054/DemRes.2006.14.14.

Kreyenfeld, M. (2002). Time-squeeze, partner effect or self-selection? An investigation into the positive effect of women's education on second birth risks in West Germany. Demographic Research 7(2): 15-48. doi:10.4054/DemRes.2002.7.2.

Kreyenfeld, M., Huinink, J., Trappe, H., and Walke, R. (2012). DemoDiff: A dataset for the study of family change in Eastern (and Western) Germany. Schmollers Jahrbuch 132(4): 653-659. doi:10.3790/schm.132.4.653.

Luppi, F. (2016). When is the second one coming? The effect of couple's subjective well-being following the onset of parenthood. European Journal of Population 32(3): 421-444. doi:10.1007/s10680-016-9388-y.

Lutz, K., Buhr, P., and Boehnke, M. (2013). Die Bedeutung der Erfahrungen mit dem ersten Kind für die Intention zur Familienerweiterung [The importance of the experiences with the first child for the intention to extend the family]. Zeitschrift für Soziologie der Erziehung und Sozialisation 33(2): 167-184.

McDonald, P.F. (2013). Societal foundations for explaining fertility: Gender equity. Demographic Research 28(34): 981-994. doi:10.4054/DemRes.2013.28.34. 
Mencarini, L. (2014). Gender equity. In: Michalos, A.C. (ed.). Encyclopedia of quality of life and well-being research. Dordrecht: Springer Netherlands: 2437-2438. doi:10.1007/978-94-007-0753-5_1131.

Mencarini, L. (2018). Does gender equality affect fertility decisions in Europe? In: Gauthier, A.H., Kotowska, I.E., and Vono de Vilhena, D. (eds.). Gender (in)equality over the life course: Evidence from the Generations and Gender Programme. Berlin: Population Europe (Discussion Paper 10): 4-8: https://www.population-europe.eu/discussion-paper/gender-inequality-over-lifecourse.

Meuwly, N., Wilhelm, P., Eicher, V., and Perrez, M. (2011). Welchen Einfluss hat die Aufteilung von Hausarbeit und Kinderbetreuung auf Partnerschaftskonflikte und Partnerschaftszufriedenheit bei berufstätigen Paaren [What is the impact of the division of housework and childcare on conflict and satisfaction among dualearner couples?]. Zeitschrift für Familienforschung 23(1): 37-56.

Miettinen, A., Lainiala, L., and Rotkirch, A. (2015). Women's housework decreases fertility: Evidence from a longitudinal study among Finnish couples. Acta Sociologica 58(2): 139-154. doi:10.1177/0001699315572028.

Mills, M. (2010). Gender roles, gender (in)equality and fertility: An empirical test of five gender equity indices. Canadian Studies in Population 37(3-4): 445-474. doi:10.25336/P6131Q.

Mills, M., Mencarini, L., Tanturri, M.L., and Begall, K. (2008). Gender equity and fertility intentions in Italy and the Netherlands. Demographic Research 18(1): 1-26. doi:10.4054/DemRes.2008.18.1.

Müller, B. and Castiglioni, L. (2015). Attrition im Beziehungs- und Familienpanel pairfam [Attrition in the German Family Panel pairfam]. In: Schupp, J. and Wolf, C. (eds.). Nonresponse bias: Qualitätssicherung sozialwissenschaftlicher Umfragen. Wiesbaden: Springer: 383-408. doi:10.1007/978-3-658-10459-7_12.

Nagase, N. and Brinton, M.C. (2017). The gender division of labor and second births: Labor market institutions and fertility in Japan. Demographic Research 36(11): 339-370. doi:10.4054/DemRes.2017.36.11.

Neyer, G., Lappegård, T., and Vignoli, D. (2013). Gender equality and fertility: Which equality matters? European Journal of Population 29(3): 245-272. doi:10.1007/ s10680-013-9292-7. 
Nitsche, N. and Grunow, D. (2016). Housework over the course of relationships: Gender ideology, resources, and the division of housework from a growth curve perspective. Advances in Life Course Research 29(1): 80-94. doi:10.1016/ j.alcr.2016.02.001.

OECD (2017). The pursuit of gender equality: An uphill battle. Paris: OECD. doi:10.1787/9789264281318-en.

Oláh, L.S. and Gähler, M. (2014). Gender equality perceptions, division of paid and unpaid work, and partnership dissolution in Sweden. Social Forces 93(2): 571594. doi:10.1093/sf/sou066.

Perales, F., Baxter, J., and Tai, T.-o. (2015). Gender, justice and work: A distributive approach to perceptions of housework fairness. Social Science Research 51(1): 51-63. doi:10.1016/j.ssresearch.2014.12.010.

Ruppanner, L., Bernhardt, E., and Brandén, M. (2017). Division of housework and his and her view of housework fairness: A typology of Swedish couples. Demographic Research 36(16): 501-524. doi:10.4054/DemRes.2017.36.16.

Schröder, M. (2018). How working hours influence the life satisfaction of childless men and women, fathers and mothers in Germany. Zeitschrift für Soziologie 47(1): 65-82. doi:10.1515/zfsoz-2018-1004.

Sechrist, J., Suitor, J.J., Howard, A.R., and Pillemer, K. (2014). Perceptions of equity, balance of support exchange, and mother-adult child relations. Journal of Marriage and Family 76(2): 285-299. doi:10.1111/jomf.12102.

Stein, P., Willen, S., and Pavetic, M. (2014). Couples' fertility decision-making. Demographic Research 30(63): 1697-1732. doi:10.4054/DemRes.2014.30.63.

Stevens, D.P., Kiger, G., and Mannon, S.E. (2005). Domestic labor and marital satisfaction: How much or how satisfied? Marriage and Family Review 37(4): 49-67. doi:10.1300/J002v37n04_04.

Torr, B.M. and Short, S.E. (2004). Second births and the second shift: A research note on gender equity and fertility. Population and Development Review 30(1): 109130. doi:10.1111/j.1728-4457.2004.00005.x.

Trappe, H. (2017). East Germany. In: Razzu, G. (ed.). Gender inequality in the eastern European labour market: Twenty-five years of transition since the fall of communism. London: Routledge: 77-99. doi:10.4324/9781315657400-4. 
Trappe, H. and Köppen, K. (2014). Familienkulturen in Ost- und Westdeutschland: Zum Gerechtigkeitsempfinden der Arbeitsteilung innerhalb der Partnerschaft [Family cultures in East and West Germany: On the perception of fairness in relation to the division of labor within couples]. In: Steinbach, A., Hennig, M., and Arránz Becker, O. (eds.). Familie im Fokus der Wissenschaft. Wiesbaden: Springer: 257-297. doi:10.1007/978-3-658-02895-4_11.

Trappe, H., Pollmann-Schult, M., and Schmitt, C. (2015). The rise and decline of the male breadwinner model: Institutional underpinnings and future expectations. European Sociological Review 31(2): 230-242. doi:10.1093/esr/jcv015. 


\section{Appendix}

\section{Table A-1: Discrete-time logistic regression model of the transition to first birth (with robust standard errors)}

\begin{tabular}{|c|c|c|c|c|c|c|}
\hline & \multirow{2}{*}{\multicolumn{2}{|c|}{$\begin{array}{l}\text { All } \\
\text { Model } 1\end{array}$}} & \multirow{2}{*}{\multicolumn{2}{|c|}{$\begin{array}{l}\text { Men } \\
\text { Model } 2\end{array}$}} & \multirow{2}{*}{$\begin{array}{l}\text { Women } \\
\text { Model } 3\end{array}$} & \multirow[b]{3}{*}{ s.e. } \\
\hline & & & & & & \\
\hline & b & s.e. & b & s.e. & b & \\
\hline \multicolumn{7}{|c|}{ Couples' employment arrangements (ref.: both full-time) } \\
\hline $\begin{array}{l}\text { Man full-time / woman part-time or } \\
\text { marginally employed }\end{array}$ & -0.01 & 0.17 & -0.09 & 0.25 & 0.02 & 0.23 \\
\hline Man and/or woman in education & $-0.33^{* *}$ & 0.10 & -0.52 ** & 0.13 & -0.19 & 0.17 \\
\hline Other combinations & -0.10 & 0.12 & -0.11 & 0.18 & -0.12 & 0.16 \\
\hline \multicolumn{7}{|l|}{ Division of housework (ref.: 50/50) } \\
\hline Completely or mainly done by woman & 0.19 * & 0.12 & 0.19 & 0.18 & 0.19 & 0.17 \\
\hline Completely or mainly done by man & -0.15 & 0.24 & 0.03 & 0.39 & -0.40 & 0.28 \\
\hline \multicolumn{7}{|l|}{ Perception of fairness (ref.: fair to both) } \\
\hline Unfair to the woman & $-0.19 *$ & 0.09 & -0.29 & 0.14 & -0.13 & 0.12 \\
\hline Unfair to the man & 0.00 & 0.19 & -0.08 & 0.26 & 0.07 & 0.30 \\
\hline Years since age 14 & $0.12^{* \star *}$ & 0.02 & $0.17^{* \star *}$ & 0.03 & $0.08^{\star \star \star}$ & 0.02 \\
\hline Duration of cohabitation (cont.) & 0.00 & 0.02 & -0.03 & 0.03 & 0.01 & 0.02 \\
\hline Respondent is a woman (ref.: man) & -0.07 & & - & - & - & - \\
\hline \multicolumn{7}{|l|}{ Place of birth (ref.: Western Germany) } \\
\hline Eastern Germany & 0.14 & 0.12 & 0.04 & 0.16 & 0.26 * & 0.19 \\
\hline Abroad & -0.13 & 0.17 & -0.19 & 0.22 & 0.12 & 0.25 \\
\hline Couple is cohabiting (ref.: married) & -0.61 *** & 0.06 & -0.74 *** & 0.08 & $-0.51^{\star \star *}$ & 0.09 \\
\hline Importance of children $(0-10)$ & $0.42^{\star \star *}$ & 0.07 & $0.44^{* * *}$ & 0.11 & $0.42^{* \star *}$ & 0.10 \\
\hline Importance of a career $(0-10)$ & $-0.12^{* *}$ & 0.05 & -0.07 & 0.07 & $-0.16^{\star \star}$ & 0.07 \\
\hline \multicolumn{7}{|c|}{ Couples' education (ref.: both vocational degree) } \\
\hline Both no degree & -0.19 & 0.23 & -0.05 & 0.35 & -0.25 & 0.31 \\
\hline Both university degree & 0.25 * & 0.16 & $0.43^{* *}$ & 0.29 & 0.12 & 0.19 \\
\hline Her education lower than his & $-0.41^{\star \star \star}$ & 0.09 & -0.50 ** & 0.13 & -0.33 & 0.15 \\
\hline His education lower than hers & -0.19 & 0.11 & 0.18 & 0.24 & $-0.44^{\star \star}$ & 0.12 \\
\hline Constant & -3.59 *** & 0.01 & $-4.34^{\star \star \star *}$ & 0.01 & $-3.23^{* \star \star}$ & 0.02 \\
\hline Wald $x^{2}$ & 375.24 & & 214.56 & & 201.27 & \\
\hline Pseudo $\mathrm{R}^{2}$ & 0.13 & & 0.15 & & 0.13 & \\
\hline Events / Person-years & $568 / 6,683$ & & $267 / 3,029$ & & $301 / 3,654$ & \\
\hline
\end{tabular}

Note: Controlled for missing information on employment arrangement, division of housework, and fairness perception (omitted from the table). ${ }^{* *} p<0.01,{ }^{* *} p<0.05,{ }^{*} p<0.1$.

Source: German Family Panel 2008/2009-2016/2017 (waves 1-9), cohorts 1981-1983, 1991-1993. 
Köppen \& Trappe: The gendered division of labor and its perceived fairness

\section{Table A-2: Discrete-time logistic regression model of the transition to second birth (with robust standard errors)}

\begin{tabular}{|c|c|c|c|c|c|c|}
\hline & \multicolumn{2}{|l|}{$\begin{array}{l}\text { All } \\
\text { Model } 4\end{array}$} & \multicolumn{2}{|l|}{$\begin{array}{l}\text { Men } \\
\text { Model } 5\end{array}$} & \multicolumn{2}{|l|}{$\begin{array}{l}\text { Women } \\
\text { Model } 6\end{array}$} \\
\hline & b & s.e. & b & s.e. & b & s.e. \\
\hline \multicolumn{7}{|c|}{ Couples' employment arrangements (ref.: both full-time) } \\
\hline $\begin{array}{l}\text { Man full-time / woman part-time or } \\
\text { marginally employed }\end{array}$ & -0.14 & 0.18 & 0.19 & 0.31 & -0.33 & 0.22 \\
\hline Man full-time / woman parental leave & $-0.73^{* \star *}$ & 0.19 & -0.29 & 0.32 & -1.02 *** & 0.24 \\
\hline Man and/or woman in education & -0.18 & 0.19 & -0.09 & 0.32 & -0.18 & 0.24 \\
\hline Other combinations & $-0.70^{* \star *}$ & 0.20 & -0.28 & 0.35 & $-0.93^{* \star *}$ & 0.26 \\
\hline \multicolumn{7}{|l|}{ Division of housework (ref.: 50/50) } \\
\hline Completely or mainly done by woman & 0.25 ** & 0.12 & 0.20 & 0.19 & 0.28 * & 0.16 \\
\hline Completely or mainly done by man & 0.38 & 0.33 & -0.01 & 0.55 & 0.46 & 0.40 \\
\hline \multicolumn{7}{|l|}{ Division of child care (ref.: 50/50) } \\
\hline Completely or mainly done by woman & 0.10 & 0.12 & 0.22 & 0.21 & -0.02 & 0.15 \\
\hline Completely or mainly done by man & -0.09 & 0.35 & -0.34 & 0.71 & -0.02 & 0.41 \\
\hline \multicolumn{7}{|l|}{ Perception of fairness (ref.: fair to both) } \\
\hline Unfair to the woman & -0.18 & 0.12 & -0.20 & 0.21 & -0.11 & 0.13 \\
\hline Unfair to the man & -0.07 & 0.35 & 0.04 & 0.33 & -0.31 & 0.33 \\
\hline Years since first birth & 0.04 & 0.03 & 0.04 & 0.06 & 0.04 & 0.04 \\
\hline Duration of cohabitation (cont.) & $0.05^{* * *}$ & 0.03 & 0.04 & 0.03 & 0.06 ** & 0.02 \\
\hline Respondent is a woman (ref.: man) & -0.14 & 0.11 & - & - & - & - \\
\hline \multicolumn{7}{|l|}{ Place of birth (ref.: western Germany) } \\
\hline Eastern Germany & $-0.30 * \star *$ & 0.12 & -0.17 & 0.19 & $-0.42^{* * *}$ & 0.15 \\
\hline Abroad & -0.29 * & 0.15 & -0.36 & 0.27 & -0.29 & 0.19 \\
\hline Couple is cohabiting (ref.: married) & -0.69 *** & 0.13 & $-0.65^{* \star *}$ & 0.21 & $-0.74^{* * *}$ & 0.17 \\
\hline Importance of children (0-10) & $0.33^{\star \star \star}$ & 0.05 & $0.36^{\star \star *}$ & 0.11 & $0.31^{* \star *}$ & 0.06 \\
\hline Importance of a career $(0-10)$ & $-0.12^{* \star}$ & 0.06 & 0.03 & 0.09 & $-0.22^{* \star *}$ & 0.07 \\
\hline \multicolumn{7}{|c|}{ Couples' education (ref.: both vocational degree) } \\
\hline Both no degree & 0.23 & 0.24 & 0.32 & 0.39 & 0.11 & 0.33 \\
\hline Both university degree & $0.88^{* * *}$ & 0.14 & 0.46 * & 0.25 & $1.12^{* * *}$ & 0.17 \\
\hline Her education lower than his & $0.43^{* * *}$ & 0.14 & 0.30 & 0.22 & $0.46^{* *}$ & 0.19 \\
\hline His education lower than hers & $0.40^{* \star \star}$ & 0.14 & 0.45 * & 0.26 & 0.38 ** & 0.19 \\
\hline Constant & $-2.12^{* \star *}$ & 0.28 & $-2.76^{* \star *}$ & 0.51 & $-1.88^{* * *}$ & 0.34 \\
\hline Wald $x^{2}$ & 209.64 & & 49.74 & & 188.34 & \\
\hline Pseudo $\mathrm{R}^{2}$ & 0.09 & & 0.07 & & 0.11 & \\
\hline Events / Person-years & $492 / 3,392$ & & $185 / 1,315$ & & $307 / 2,077$ & \\
\hline
\end{tabular}

Note: ${ }^{* *} \mathrm{p}<0.01,{ }^{* \star} \mathrm{p}<0.05,{ }^{*} \mathrm{p}<0.1$.

Source: German Family Panel 2008/2009-2016/2017 (waves 1-9), cohorts 1981-1983, 1991-1993. 